\title{
Sociedade civil, partidos políticos e inter-relações: um estudo comparativo entre Porto Alegre e Montevidéu
}

\author{
Alejandro Lezcano Schwarzkopf $^{1}$
}

\begin{abstract}
Este artigo tem o propósito de realizar um estudo comparativo entre o orçamento participativo de Porto Alegre e a descentralização participativa de Montevidéu, tendo como centro analítico o papel desempenhado pelos sistemas políticopartidários nos dois países. Nesse sentido, a investigação pretende oferecer elementos que auxiliem a responder à seguinte pergunta: até que ponto a natureza distinta dos sistemas partidários do Brasil e do Uruguai e suas ligações com a sociedade civil afetam a criação e o funcionamento das novas instituições participativas? $\mathrm{Na}$ análise buscou-se romper com a dicotomia normativa que separa a sociedade civil da sociedade política, presente em grande parte dos trabalhos acadêmicos sobre instituições participativas no Brasil. Após investigação baseada em fontes secundárias sobre as duas experiências e fontes primárias (entrevistas realizadas com integrantes dos Conselhos de Vizinhos, em Montevidéu, e com delegados do OP, em Porto Alegre), concluiu-se pelas influências distintas dos sistemas políticos nos casos estudados. Em Montevidéu, predomina, hegemonicamente, a participação de pessoas com uma longa trajetória na política partidária. No caso do OP de Porto Alegre, a baixa institucionalização do sistema político-partidário permitiu que os participantes não fossem constrangidos pelas identidades partidárias.
\end{abstract}

Palavras-chave: democracia participativa; sociedade civil; partidos políticos

\section{Introdução}

Com o triunfo eleitoral da Frente Popular na cidade de Porto Alegre em 1989, o orçamento participativo (OP) transformou-se em uma grande inovação democrática que foi modelo para centenas de cidades no mundo. Entre elas Montevidéu, cidade que incorporou uma nova forma de participação da sociedade civil: a descentralização participativa (DP) e a instalação de centros comunais zonais (CCZs).

As organizações políticas que impulsionaram essas novas formas de participação, o Partido dos Trabalhadores (PT) e a Frente Ampla (FA), podem ser consideradas partidos de massa, segundo a classificação clássica de Duverger (1980), isto é, partidos com fortes vínculos extraparlamentares em diferentes organizações da sociedade civil.

\footnotetext{
1 Universidade Federal de Santa Maria. Santa Maria (RS), Brasil. E-mail: <alejandro@politecnico.ufsm.br>.
} 
Esse aspecto em comum contrasta com as marcadas diferenças dos sistemas e cultura política em que atuaram.

A cultura política uruguaia, durante grande parte do século $X X$, destacou-se por ter na esfera partidária um de seus principais centros de organização social. Os partidos predominaram sobre diferentes formas corporativas de representação. Essa centralidade foi revigorada nas últimas décadas pela presença política da FA nos governos da capital e do país.

Em termos comparativos, no contexto latino-americano Uruguai aparece como um país com partidos fortes e institucionalizados, no qual o Estado e o sistema político, em geral, impulsionaram as mudanças econômicas e sociais. Esse diagnóstico atravessa, nas ciências sociais, toda a produção acadêmica uruguaia. Esse sistema partidário aparece classificado como altamente institucionalizado, contrastando com o sistema de partidos brasileiro, classificado na categoria incoativo, isto é, com fraca institucionalização, alta volatilidade eleitoral, poucas raízes sociais e personalidades acima das instituições (Mainwaring e Scully, 1995).

Dessa forma, este artigo apresenta casos antagônicos de institucionalização partidária e de confiança no sistema político. Por um lado, o Uruguai, que segundo dados do Latinobarómetro (2013) apresenta os mais elevados índices de apoio à democracia e confiança no sistema partidário; por outro lado, o Brasil, que tem o menor grau de institucionalização partidária da América Latina, apresentando um sistema partidário fragmentário, com baixa identificação e confiança entre seus eleitores.

Segundo Goldfrank (2006), nas implementações das novas instituições participativas (IP), o nível de institucionalização dos partidos de oposição criou diferenças na participação nas experiências de Montevidéu e de Porto Alegre. Em Montevidéu, o novo partido no governo, a FA, enfrentou partidos de oposição fortemente institucionalizados e com redes clientelísticas com ampla identificação partidária, com raízes nos primeiros anos do século XIX.

Para esse autor, em Porto Alegre, não existiam grupos partidários historicamente dominantes, vários deles foram formados nas últimas décadas, com pouca coerência programática e disciplina partidária. "El PT era sólo un partido más entre varios débilmente institucionalizados" (Goldfrank, 2006, p. 14).

A diferença implicou que, quando a FA tentou introduzir programas de participação, seus oponentes tinham mais a perder comparativamente aos rivais do PT.

Dessa forma, a resistência dos grupos de oposição foi mais forte em Montevidéu. No caso de Porto Alegre, o PT teve maior liberdade no desenho do OP. Outra consequência da oposição debilmente institucionalizada foi que as organizações comunitárias de Porto Alegre tiveram mais autonomia frente aos agrupamentos políticos.

Entendemos que o argumento de Goldfrank é válido em relação ao sistema político brasileiro em geral, mas não se aplica totalmente à dinâmica partidária do Rio Grande do Sul e ao caso particular do PT. Pois essa organização política já tinha 
alcançado características de partido institucionalizado no final da década de 1980 . Samuels (1999) destaca que, mesmo com um sistema eleitoral altamente centrado no candidato, o PT conseguiu desenvolver mecanismos de reforço da reputação partidária e, dessa forma, criou uma estrutura organizacional diferente da dos demais partidos brasileiros. Como consequência, afirma: "Somente o PT tem sido capaz de construir e manter uma ampla base de 'identificados' com o partido entre os eleitores brasileiros" (Samuels, 2008, p. 303).

Em sistemas pouco institucionalizados, como o brasileiro, existe baixa identificação dos eleitores com organizações partidárias. Entretanto, rompendo com essas características, o PT sozinho responderia por 65,6\% das identificações partidárias no Brasil (Klein, 2007). Em relação ao sistema partidário do Rio Grande do Sul (RS), Trindade e Noll (1991) encontram na história partidária gaúcha uma clivagem políticoeleitoral com polarizações próximas às platinas e dicotomias que atravessam rupturas nos sistemas partidários nacionais. Esse padrão se manteve até a gênese do OP.

$\mathrm{Na}$ particularidade gaúcha o legado trabalhista sobreviveu à ruptura do sistema partidário produzida em 1964, desempenhando um peso relevante na reestruturação partidária na abertura democrática. Assim, o Partido Democrático Trabalhista (PDT), fundado por Leonel Brizola, é construído no estado por meio das redes sociais e familiares do trabalhismo anteriores ao golpe de 1964 (Grill, 2004).

A partir dessas considerações, as hipóteses de Goldfrank (2002) são guias adotados como parciais para a compreensão da influência do sistema político na participação da sociedade civil, pois o sistema político brasileiro tem baixa institucionalização, mas o PT e os partidos de esquerda, como o PDT gaúcho dos finais da década de 1980, têm características diferenciadas com importantes graus de institucionalização.

O objetivo deste artigo é encontrar elementos nos sistemas partidários analisados que possam influenciar o funcionamento das IPs nas cidades de Montevidéu e Porto Alegre. O método proposto para alcançar esse objetivo centra-se na análise empírica do terreno das vinculações, articulações e permeabilidades entre as esferas da sociedade civil e da sociedade política.

Focalizar a influência partidária na análise das IPs muda a perspectiva centrada na sociedade civil, pois os estudos sobre participação no Brasil negligenciaram a influência exercida pelo sistema partidário nessas instituições. A literatura centrada na "sociedade civil", que tem como referências centrais as obras de Habermas (2003), Cohen e Arato (2001) e Avritzer (1996), apontou seu foco analítico na dinâmica deliberativa no interior dos espaços de participação ou nos aspectos gerais que promovem uma maior democratização da sociedade. Essa literatura enfatiza a autonomia como fundamento do potencial transformador da sociedade.

Entretanto, essa perspectiva realiza poucas distinções analíticas entre os atores da sociedade civil e dá pouca atenção aos fatores que configuram as diferentes 
capacidades dos atores para a ação. Assim, nosso ponto de partida visa a romper com a dicotomia normativa que separa a sociedade civil da sociedade política.

Houtzager, Gurza Lavalle e Acharya (2004), a partir das críticas a essa perspectiva, buscam mecanismos teóricos que iluminem os espaços de ação entre a sociedade civil e a sociedade política. Nesse sentido, destacam que a capacidade de participar está condicionada pela história da construção dos atores e pelas suas relações com outros atores (do Estado ou do universo das organizações civis). Eles denominam essa abordagem de "perspectiva da polis",

em contraposição à perspectiva da sociedade civil - que destaca como foco principal a autonomia das organizações da sociedade civil e que dá pouca importância às instituições políticas, a perspectiva da polis aponta que organizações civis com fortes vínculos com atores políticos, movimentos operários ou atores estatais são mais propensas a participar (Houtzager, Gurza Lavalle e Acharya, 2004, p. 3).

O presente artigo está focalizado nos elementos apontados na perspectiva da polis. Assim, analisamos as esferas de representação vinculadas a locais geográficos nas duas instituições participativas ${ }^{2}$, isto é, a pesquisa terá como objeto empírico a comparação entre os Conselhos de Vizinhança (CV) de Montevidéu e os Fóruns de delegados do OP de Porto Alegre (PoA). Essas estruturas institucionais, relacionadas respectivamente à descentralização participativa de Montevidéu e ao orçamento participativo de PoA, são bastante análogas entre si. Nos dois casos existem cidadãos que são eleitos e representam regiões e interesses de bairros das cidades.

O artigo está estruturado da seguinte forma: na primeira seção, "Questões metodológicas", descrevemos os procedimentos metodológicos utilizados na comparação. Também nela analisamos o formato institucional das IPs de Montevidéu e Porto Alegre. Na segunda seção, "Sociedade civil e partidos na gênese das IPs", comparamos os vínculos existentes entre a sociedade civil organizada e o sistema político-partidário em ambas as cidades. Na terceira seção, "Comparação dos sistemas políticos, inserção dos partidos na sociedade", comparamos os sistemas políticos e das inserções dos partidos na sociedade. Finalmente, nas últimas duas seções, "Influência da dinâmica político-partidária nas IPs" e "Dinâmicas partidárias e mudanças na participação na década de 2000", a partir das entrevistas realizadas ${ }^{3}$, comparamos o impacto do sistema partidário na forma de participação dos delegados e conselheiros.

\footnotetext{
2 A escolha de órgãos representativos vinculados ao espaço geográfico visa a encontrar homologias institucionais, para dessa forma separar os efeitos da variável partidária dos de outros elementos, como, por exemplo, variáveis referentes às normas e, consequentemente, ao desenho institucional que interfere no desempenho dessas novas instituições.

3 Arquivo com todas as entrevistas está disponível na página do artigo no site do Cesop, seção Opinião Pública: <https://www.cesop.unicamp.br/por/opiniao_publica>.
} 


\section{Questões metodológicas}

A partir de outros estudos comparativos sobre a participação em Montevidéu e Porto Alegre, como os de Goldfrank (2002, 2006), Gugliano (2004), Ribeiro e Borba (2010) e das pesquisas de campo, realizadas em 2013 e 2014, buscamos encontrar elementos do sistema político partidário que influenciem a participação da sociedade civil.

O artigo não visa a encontrar no sistema político um fator causal que hipoteticamente tenderia a produzir impactos, efeitos ou resultados similares, independentes dos contextos de implementação e das características de cada IP. Entretanto, a partir dos dados empíricos analisados, apresentamos hipóteses para posteriores explorações sistemáticas mais amplas nas fronteiras e inter-relações existentes entre os partidos políticos e a ação dos atores da sociedade civil.

Comparar implica fundamentalmente encontrar semelhanças e diferenças. Se duas entidades são iguais em tudo, em todas as suas características, é como se fossem a mesma entidade. Se ocorre o inverso, duas entidades são diferentes em tudo, é inútil compará-las. As comparações que interessam são entre as entidades que possuem atributos, em parte, compartilhados e, em parte, não compartilhados (Sartori, 1994).

Baseados nessa estratégia comparativa, analisamos cidades com perfis sociodemográficos similares, que se aproximam nas características populacionais, na taxa de urbanização e na incidência da desigualdade medida pelo índice de Gini. O conceito que está por trás dessa escolha é a aproximação das características estruturais para, então, aferir a influência da variável política sobre a participação da sociedade civil.

No caso de nosso artigo, podemos enumerar aspectos em comum que demarcam uma aproximação: a redemocratização dos dois países na metade da década de 1980; a reforma do Estado e a valorização da sociedade civil; a descentralização política e administrativa na década de 1990; o fato de Montevidéu ter uma população de aproximadamente 1.325.968 habitantes e índice de desenvolvimento humano (IDH) de 0,880 (Atlas, 2013), ao passo que Porto Alegre tem 1.409.351 habitantes e IDH de 0,805 , segundo o IBGE de 2014.

Os elementos em comum das cidades não se mantêm na comparação entre os Estados, pois Brasil e Uruguai são países muito diferentes entre si. Enquanto o Brasil possui uma população estimada de quase 200 milhões de habitantes, o Uruguai não chega a 3,5 milhões, dos quais aproximadamente $50 \%$ estão concentrados na capital, Montevidéu. O território brasileiro é cerca de 50 vezes maior do que o uruguaio, segundo menor da América do Sul.

Do ponto de vista da organização política, embora os dois países adotem sistema presidencialista e representação proporcional, o Brasil forma uma federação e o Uruguai, um Estado unitário. O Uruguai apresenta um sistema partidário (com um sistema eleitoral de listas fechadas) classificado como institucionalizado estável, cujas mais tradicionais legendas são centenárias (Partido Colorado e Partido Nacional) (Barreto, 
2012). Já o Brasil tem um dos sistemas partidários menos institucionalizados da América Latina e um sistema eleitoral de listas abertas (Mainwaring e Scully, 1995).

No Uruguai, a estrutura subnacional está dividida em 19 departamentos, nos quais o Poder Executivo é exercido pelo intendente, eleito diretamente pela população e que, ao contrário do presidente, pode concorrer imediatamente a um novo governo. Cada departamento reúne diversas cidades, vilas ou povoados, mas não corresponde plenamente nem aos municípios nem aos estados brasileiros.

O intendente é uma figura mista, está a meio caminho de ser o governador do departamento e o prefeito da capital departamental (Cardarello, 2009). É na esfera municipal que, no final da década de 1980, vai ser estabelecida a descentralização participativa.

Na capital uruguaia, o primeiro objetivo da DP foi o de descentralizar os serviços, para depois descentralizar o orçamento. A inovação mais importante foi a criação dos Conselhos de Vizinhança (CVs) (Gugliano, 2004). Em Montevidéu, existem 18 CVs, os quais têm como objetivo ser porta-vozes das propostas e das soluções dos problemas do bairro ante as autoridades municipais e nacionais. Eles são os protagonistas na elaboração de planos e projetos de caráter zonal, assim como na elaboração do orçamento municipal, na definição de prioridades de gastos e investimentos.

Cada CV é composto por no mínimo 5 até 40 representantes, os quais são escolhidos pelos vizinhos residentes em cada zona. Nas eleições secretas, podem participar todas as pessoas maiores de 18 anos que tenham sido apoiadas por uma organização social ou pela assinatura de dez pessoas residentes no bairro ou na zona onde funcione o CV. A participação dos conselheiros é honorífica. Eles realizam atividades culturais, sociais e esportivas, coordenam ações com outros conselheiros vicinais e cooperam na manutenção de obras de infraestrutura, de esportes, de parques e de áreas verdes.

As questões relacionadas ao orçamento são introduzidas em 2006. Nesse ano são criadas novas regras, elaboradas e aprovadas em conjunto pelo governo municipal e pelos CVs. A nova regulamentação estabelece duas fontes de recursos orçamentais: Fonte 1 e Fonte 2.

A Fonte 1 está composta por recursos orçamentais definidos pelo intendente municipal em cada período anual e é igual para cada uma das 18 regiões em que se divide Montevidéu. O destino dessa fonte orçamentária é decidido pela cidadania, mediante voto direto e universal em eleições convocadas para essa finalidade.

A Fonte 2 está integrada por recursos para obras das secretarias executivas da intendência. A utilização desses recursos é decidida pelos CVs, em consulta com os moradores dos bairros. O novo mecanismo assegura o direito de participação universal, possibilitando que cidadãos maiores de 16 anos possam propor obras e decidir quais delas serão realizadas, mediante uma eleição com voto secreto. 
No caso brasileiro, optou-se por estimular inicialmente um processo de participação da população na gestão financeira da cidade. Em Porto Alegre, predominou uma estrutura baseada em assembleias. A cidade foi dividida em 16 regiões. Anualmente são realizadas assembleias em cada uma das regiões e seis plenárias temáticas (Saúde e Assistência Social, Educação, Esporte e Lazer, Tributação, Circulação e Transporte). As assembleias são abertas a todos os cidadãos com idade a partir dos 16 anos, quando já têm o direito a votar e ser votado.

A comunidade também elege parte dos delegados que irão representá-la no Fórum de Delegados. Essa fórmula de representação cria incentivos para a mobilização o número de delegados alocados para cada região cresce em função marginal decrescente (Fung, 2004). Os delegados podem ser eleitos ou indicados (pelas organizações sociais e/ou comunidade de determinado bairro) em momento posterior às assembleias. O conselho do OP reúne-se periodicamente e é a principal instância de discussão e decisão de prioridades.

A distribuição de recursos entre as regiões/temáticas baseia-se na aplicação de critérios objetivos, impessoais e universais, decididos todos os anos pelos representantes do conselho do orçamento participativo (COP) e pelo Executivo (Fedozzi e Martins, 2013).

Ao analisar os efeitos do sistema político-partidário na participação, avaliamos a maneira como os dois sistemas estudados estimulam ou limitam a participação de atores da sociedade civil e influem na consolidação de modelos institucionais. Assim, comparamos os vínculos dos conselheiros dos CVs e os delegados do OP de PoA com organizações sociais e partidos políticos; nos dois casos existe representação de regiões. Essa última comparação adota como recorte empírico duas regiões análogas de cada cidade quanto ao nível socioeconômico (baixo e médio) da população.

Nossa análise foi focalizada em dois centros comunais zonais $(C C Z)^{4}$ de Montevidéu e duas regiões de Porto Alegre. A escolha dos territórios foi direcionada para o objetivo de encontrar elementos socioeconômicos análogos nas duas cidades. Para essa finalidade metodológica foram selecionados nas duas capitais dois tipos de regiões: uma região com menor índice de acesso a bens e serviços públicos e outra com acesso médio.

Na cidade de Montevidéu realizamos 21 entrevistas somadas nos CC3 e no CC17. $\mathrm{Na}$ cidade de Porto Alegre, onde existem mais pesquisas, realizamos 14 na região Glória e na região Noroeste. Também realizamos entrevistas com funcionários que participaram da elaboração da engenharia institucional da descentralização participativa.

Nos roteiros procuramos analisar parte das trajetórias individuais dos conselheiros e delegados, seus vínculos com organizações da sociedade civil e do sistema político (medidos pelo tipo de organização com que se relacionam, de base territorial, como as associações de moradores, ou organizações setoriais, como sindicatos), o tempo

\footnotetext{
${ }^{4}$ A cidade de Montevidéu foi dividida em 18 centros administrativos (CCZ), vinculados aos 18 Conselhos de Vizinhança, CC1 a CC18.
} 
SOCIEDADE CIVIL, PARTIDOS POLÍTICOS E INTER-RELAÇÕES: UM ESTUDO COMPARATIVO ENTRE PORTO ALEGRE E MONTEVIDÉU

de participação na vida pública e particularmente suas relações com partidos políticos, a fim de captar diferentes visões sobre a avaliação do funcionamento das instituições participativas.

\section{Sociedade civil e partidos na gênese das IPs}

A fraqueza dos partidos na sociedade brasileira contrasta com a amplíssima variedade de canais de representação extraparlamentar. As novas formas de representação surgidas após a Constituição de 1988 caracterizam-se por suas funções de fiscalização e gestão de políticas públicas realizadas por cidadãos ou, no caso do OP, pela possibilidade de decidirem sobre parte do orçamento municipal. A Constituição de 1988 possibilitou a abertura de canais democráticos. A academia brasileira deu um importante destaque ao papel dos diversos setores da sociedade civil no processo de democratização em diferentes âmbitos e temas: na luta contra o governo autoritário; nas reivindicações relativas à problemática urbana; na reformulação na esfera dos valores. A década de 1970 caracterizou-se como um marco no desenvolvimento da ideia de sociedade civil e do associativismo plural autônomo. As explicações para esse novo associativismo relacionaram-se à configuração autoritária da ditadura militar. Nesse contexto, um novo associativismo combativo irrompe na esfera pública, denunciando injustiças e lutando pela democratização. Os movimentos sociais passam a representar a ideia de sociedade civil que, contraposta ao Estado, significava o campo virtuoso das ações e interações sociais que desafiavam a lógica do poder tradicional, denunciando e demandando a construção de uma sociedade mais igualitária (Avritzer, 2012; Lüchmann, 2002). Essas mudanças foram interpretadas por Avritzer (1997, p. 23) como novas formas de "ação coletiva e de ocupação do espaço público". Os atores coletivos criam um novo espaço público, distinto da sociedade política, gerando novas identidades. Nesse processo, existe uma ruptura do padrão populista (no qual predominam as relações clientelísticas verticais), reforçada a partir da entrada de atores de classe média na cena política e do aparecimento de associações temáticas, provocando um significativo aumento no ritmo de constituição de associações civis e de pluralização dos temas com os quais as associações lidam.

No contexto da redemocratização, houve mudança na atitude dos novos atores sociais, que, na década de 1970, foi caracterizada por um confronto direto com o Estado. Avritzer (2012) identifica uma nova fase das práticas dos atores da sociedade civil, marcada por uma maior interdependência com instituições do Estado. No momento pósautoritário, o associativismo urbano pauta-se menos pelo embate e mais pela negociação com o Estado; menos pela ação coletiva pública e contestatória e mais pela construção de mecanismos participativos; menos pela militância e mais pela ocupação de cargos de representação e gestão (Lüchmann, 2002). Nessa perspectiva, um dos principais momentos de atuação dos movimentos sociais junto aos canais formais de representação 
política foi o processo de elaboração da Constituição brasileira de 1988, a qual permitiu a consolidação e a abertura dos canais de participação e afirmou a possibilidade de formas de democracia direta. Foi esse marco que possibilitou a implementação, em diferentes níveis de governo, de conselhos de políticas públicas, com representantes do governo e da sociedade civil, em áreas como saúde, educação, assistência social, criança e adolescente. Também foram elaboradas as Leis Orgânicas Estaduais e Municipais - sem as quais não haveria repasse de recursos do nível federal para os níveis estadual e municipal (Teixeira e Albuquerque, 2006).

Assim, a Constituição de 1988 ensejou um âmbito favorável à criação do orçamento participativo (OP), abrindo canais de participação nos municípios, favorecendo a descentralização e fornecendo capacidades financeiras e legais que permitiram aos governos locais inovações administrativas e políticas. O novo marco legal acarretou maior descentralização, permitindo transferências de responsabilidades e de recursos financeiros para os municípios. Essa situação levou os poderes executivos municipais, especialmente os governados por partidos de esquerda, a desenvolver maior grau de autonomia e responsabilidade, realizando reformas tributárias para aumentar a arrecadação de recursos próprios.

As reformas visando à descentralização não foram exclusividade do Brasil; elas foram realizadas em vários países da América Latina, dentre eles o Uruguai. Em muitos casos, em lugar de um aprofundamento da democracia, a descentralização implicou um processo liberalizante e ocorreu uma redução das áreas de atuação do Estado por meio da delegação à sociedade civil das políticas para o terceiro setor. No caso brasileiro, a descentralização, por um lado, permitiu desconcentrar o nível de demandas no governo federal; por outro, proporcionou um novo canal para as lutas pela democratização social.

No final da década de 1980, no início da administração governamental, os novos governos de esquerda de Montevidéu e de Porto Alegre passaram por contradições e conflitos vinculados à transição do momento pré-estatal para o pós-estatal, que foram muito similares. As duas forças políticas estavam fortemente ligadas a sindicatos e movimentos sociais, realizando forte oposição aos governos anteriores. No momento de assumir a administração, vão enfrentar um novo contexto das relações entre movimentos, partido e governo ${ }^{5}$.

\footnotetext{
5 A aproximação entre o PT e as formas de democracia participativa é destacada por Avritzer (2009) e Fedozzi (2000). Em documentos do próprio partido, a avaliação é de uma relação imediata entre PT e participação popular (Genro e Souza, 1997). Nessa mesma perspectiva, Paoli (1995) destaca o PT como partido de movimento, de cultura política democrática, em luta para que os espaços políticos institucionais se desvinculassem das práticas políticas patrimonialistas, atuando na sociedade civil como um elemento externo de controle político.

A FA surge em 1971, depois de longas negociações e um abrangente acordo partidário. A nova força agregava comunistas, socialistas, democratas cristãos e segmentos progressistas que haviam deixado os partidos Nacional e Colorado. A FA construiu uma identidade política própria, uma coalizão que forma uma unidade, legitimada por acordos, consensos e maiorias democráticas. A identidade de movimento da FA estava fortalecida por um crescente número de militantes de base que se autoidentificavam como frenteamplistas, sem se alinharem a nenhum dos partidos ou grupos políticos que integravam a coalizão (Yaffé, 2013; Chaves, 2005).
} 
Entretanto, apesar desses elementos em comum, ocorrem marcadas diferenças nas relações entre movimentos sociais e os novos governos. Em Porto Alegre, a ação de um movimento comunitário exerceu forte influência no surgimento e na consolidação da participação. A gênese do OP em Porto Alegre esteve diretamente vinculada aos movimentos sociais e à participação de partidos políticos de esquerda. O êxito dos primeiros anos do OP e a qualidade do sistema de participação favoreceram-se da cultura associativa porto-alegrense, assim como das ações coletivas dos movimentos sociais e dos partidos políticos de esquerda que lutavam por direitos de cidadania no Brasil, conforme Fedozzi (2000), Gugliano (2004), Silva (2001) e Avritzer (2003).

Em Porto Alegre, setores identificados como a sociedade civil aparecem como demandantes da democratização da gestão do orçamento público. Para Avritzer (2009), o PT cumpriu o papel de conector das ideias de participação presentes na sociedade civil. Os espaços públicos abertos à participação popular foram possíveis devido ao tecido associativo e a uma cultura de direitos. O que é questionável na análise de Avritzer é a separação entre a sociedade civil e a sociedade política, pois os atores da sociedade civil e política transitam por organizações comunitárias e partidos. Nesse sentido, a partir de 1970, há um grande número de lideranças de organizações sociais que se engajam em partidos exercendo uma dupla militância. Os partidos, por meio de seus membros, agem nos movimentos sociais como militantes múltiplos (Mische, 1997). Assim, partidos e movimentos ocupam um espaço comum de participação e representação política na sociedade civil brasileira. Nesse cenário, torna-se frequente a presença, nos movimentos sociais, dos chamados agentes externos ou "sujeitos organizacionais" (Igreja, partidos políticos, ONGs), atuando e interferindo em seu funcionamento e em sua dinâmica, especialmente nas associações. Essa relação não se limita ao caso brasileiro. Com efeito, os partidos, principalmente os de esquerda, no cone sul latino-americano, tiveram estreitos vínculos com os movimentos sociais. Essas relações apresentaram diferentes características, dependendo das identidades dos partidos (Serna, 2003).

Os vínculos entre sociedade civil organizada e atores ligados a organizações político-partidárias marcaram o processo de consolidação da experiência participativa gaúcha. A União de Associações de Moradores de Porto Alegre (Uampa) manteve íntimos vínculos com os partidos políticos e muitas vezes os interesses destes últimos pautaram ações do movimento. Os congressos da década de 1980, por exemplo, foram realizados em momentos de campanhas eleitorais, o que parece indicar que esses eventos foram instrumentos dos diferentes interesses político-partidários. Na década seguinte, a Uampa vai perder influência no movimento comunitário. Contudo, como os partidos que passaram a controlar a Uampa não tinham na origem uma política específica para os movimentos comunitários, as lideranças passam a atuar com alto grau de autonomia individual para o encaminhamento de questões como a luta pelo acesso à terra e por serviços urbanos (Baierle, 1992, p. 164). É possível acrescentar a essa observação que a autonomia individual dos agentes políticos partidários estava potencializada pela baixa 
institucionalização do sistema político brasileiro. Dessa forma, muitos atores individuais vinculados a partidos pouco institucionalizados atuavam nos movimentos sociais sem nenhum tipo de constrangimento de programas ou identidades partidárias.

Em Montevidéu, não se constituiu um movimento desse tipo. A sociedade civil montevideana foi configurada principalmente com a presença de um organizado movimento sindical.

Filgueira (1985) observa na formação do sindicalismo uruguaio uma relativa autonomia em relação ao Estado e aos partidos políticos. Desde suas origens, em fins do século XIX, e particularmente durante o primeiro batllismo ${ }^{6}$ - momento inicial da incorporação política dos trabalhadores -, a ação sindical uruguaia manteve certa distância tanto do Estado como dos partidos Colorado e Nacional. A expressão dessa autonomia manifestou-se na ausência de leis que a regulassem, distinguindo-a da de seus pares em diferentes países latino-americanos; assim como na ausência de filiação a um partido, em exercício, do governo.

A formação da FA marcou um novo patamar nas relações existentes entre sindicatos e partidos. Desde então, os vínculos entre sindicatos e partidos de esquerda adquirem novos matizes. Nesse sentido, as pesquisas realizadas por Doglio, Senatore e Yaffé concluem que, desde 1971, a grande maioria de dirigentes sindicais está filiada a organizações políticas que são correntes internas da FA. Esses setores frenteamplistas têm pesos relativos diferentes e oscilantes na direção da central sindical. Também é comprovado, mediante dados empíricos, a quase completa interconexão dos sindicatos com os partidos de esquerda (Doglio, Senatore e Yaffé, 2004, p. 264).

Em relação às associações de moradores e às comissões de vizinhança, vão ganhar maior importância e densidade na sociedade civil uruguaia no começo da década de 1980, quando passam a atuar como agentes do combate à ditadura militar. Durante o regime autoritário aumentou o número de associações de moradores. Nesse período, as organizações de bairro adquirem uma atitude defensiva, visando a ganhar ou manter espaços de ação, em condições de forte repressão (Filgueira, 1985).

A partir do processo de abertura, as associações de moradores, tal como outros atores sociais e políticos, adquiriram gradativamente maior capacidade de iniciativa no processo de transição à democracia. Assim como no Brasil e em grande parte da América Latina, essa etapa se caracterizou por uma ação de natureza "extraestatal" antiditatorial, em que se estabeleceram novas organizações autônomas e outras vinculadas a sindicatos, cooperativas e partidos.

A proposta de participação da DP estabeleceu que as organizações de base territorial, em particular as associações de moradores, fossem os interlocutores privilegiados das novas instituições. Mas esse papel não surge como uma demanda das próprias organizações do bairro. Nesse aspecto, a pesquisa de Bruera (1993) conclui que,

${ }^{6}$ Corrente política inspirada nas ideias e doutrina política de Batlle e Odoñez (1856-1929). 
no contexto da implementação da DP, somente $16 \%$ dos membros das associações de moradores consideram que a função das associações é cogovernar. Ou seja, para a maioria das associações, seu papel é divergente do proposto pela intendência.

Em nossa pesquisa, a maioria dos entrevistados disse participar ou ter participado de associações de moradores ou comissões de bairro; entretanto, essa participação é muito difusa, pois os conselheiros afirmam que raramente participaram de reuniões oficiais em algum tipo de organização do bairro.

Em uma pesquisa realizada pela assistente social do CCZ 3, foi constatado que $58 \%$ dos conselheiros participaram de alguma organização de caráter social; entretanto, somente $11 \%$ dos atuais conselheiros foram apresentados por uma organização de bairro, a maioria apresentou sua candidatura mediante o procedimento de coleta de assinaturas individuais.

Portanto, apesar de existirem vínculos dos conselheiros com as organizações de bairro, esses vínculos não geram uma participação que incorpore as associações e comissões como interlocutoras e agentes de demandas. Alguns conselhos têm implementado estratégias pontuais para relacionar-se com organizações sociais e vizinhos, mas não é uma prática comum.

Todavia, alguns CVs relacionam-se fluidamente com a sociedade civil por meio de algumas comissões temáticas. Nesses casos, a vinculação do CV com a sociedade civil ocorre principalmente por estratégias individuais dos conselheiros. Por exemplo, muitos de nossos entrevistados afirmaram que participavam, de forma assídua, das comissões temáticas (particularmente da Mulher ou da Cultura). Em todos os casos, as análises mostram que os CVs orientam parte de seu trabalho apenas para a gestão interna, em detrimento do trabalho de interlocução com vizinhos e organizações sociais (Ferla et al., 2012).

Dessa forma, é possível afirmar que os partidos que impulsionaram as IPs, isto é, a FA e o PT, tiveram, no final da década de 1980, estreita interpenetração com os movimentos sociais. Entretanto, existem diferenças em relação ao tipo de movimentos a que se vinculam. No caso de Montevidéu, o modelo inicial de participação foi projetado exclusivamente por uma organização política que possui fortes vínculos com o movimento sindical. Esse projeto não foi gerado por demandas de participação de organizações da sociedade civil externas à FA.

Em Porto Alegre, setores identificados como a sociedade civil, vinculados a associações de moradores, mas com estreitos laços com partidos políticos, aparecem como demandantes da democratização do orçamento público. 


\section{Comparação dos sistemas políticos, inserção dos partidos na sociedade}

Interpretações das ciências sociais uruguaias têm privilegiado o papel dos partidos tradicionais, destacando que os partidos uruguaios funcionaram como agentes centrais do sistema político. Entre os acadêmicos uruguaios, essa ideia sempre foi destacada de forma consensual, provocando a denominação da democracia uruguaia como "partidocêntrica" (Real de Azúa, 1988)7. Assim, a cultura política uruguaia é fortemente influenciada pelo ideário dos partidos políticos, e tal caraterística relaciona-se ao processo de formação da identidade nacional, iniciada no século XIX e concluída pelo batllismo. Mais que qualquer sociedade latino-americana, o Uruguai destaca-se por ter, na esfera político-partidária, um de seus principais centros de organização social; as lealdades partidárias orientam decisivamente as práticas políticas dos uruguaios (Sousa, 2003).

Para Mainwaring e Torcal (2005), os laços fortes entre eleitores e partidos podem ser construídos por vínculos programáticos/ideológicos, clientelistas ou tradicionais/afetivos. Os partidos históricos uruguaios se aproximariam do último par, centrado em laços emocionais. Atualmente, o apelo às fortes identidades persiste por meio de outros mecanismos, baseados em vínculos mais próximos aos programáticos/ideológicos, pois a FA é uma frente de esquerda policlassista (representa adesões de vários setores sociais). Da mesma forma que os partidos Nacional e Colorado construíram suas identidades um em oposição ao outro, a FA construiu sua identidade em oposição aos partidos Branco e Colorado (Lissidini, 2002).

Os estudos sobre os partidos políticos no Brasil compartilham a ideia de que as organizações partidárias são instituições frágeis (Meneguello, 1989. Essas características institucionais favoreceriam a autonomia das disputas eleitorais dos candidatos a cargos legislativos, estimulados a fazer suas campanhas com grande independência em relação ao partido.

Entre os fatores explicativos dessa realidade, encontra-se o grau de descontinuidade dos partidos e dos sistemas partidários no contexto da formação histórica do país, uma vez que o autoritarismo foi a regra e os períodos democráticos foram a exceção. Isso provocou a inexistência de condições para a constituição de uma história partidária contínua e de memória política vinculada às organizações partidárias

\footnotetext{
7 Para Caetano e Rilla (1991), as razões e as raízes do partidocentrismo uruguaio encontram-se nas extensas e variadas funções que realizaram os partidos na sociedade. Eles interatuam de forma quase permanente e operam complementarmente em múltiplos aspectos. Os autores citam exemplos históricos de funções que extrapolam a política partidária: a superação antecipada, em relação à realidade latinoamericana, e a exclusão política das massas. Nesse sentido, no princípio do século XX, os imigrantes foram incorporados, por meio da ação dos partidos, na atividade política. Assim, a maioria da população identificou-se com o Partido Colorado ou o Partido Nacional. Entretanto, o sistema partidário contribuiu para a geração de limitações na representação de grupos sociais. Os autores destacam que os partidos promoveram a extensão de relações clientelísticas como base de sustentação do Estado, assim como a captura do social organizado pelo partidário, possibilitando uma limitação do desenvolvimento autônomo da sociedade civil.
} 
com posições ideológicas definidas. No Brasil, os partidos aparecem e desaparecem vertiginosamente. Além disso, a heterogeneidade regional e cultural brasileira, condicionada pelas dimensões continentais do país, dificultou a formação de partidos nacionais (Mainwaring, 2001).

Para Mainwaring (2001), a relação existente entre partidos pouco institucionalizados, representação proporcional, multipartidarismo, presidencialismo e um sistema de listas abertas gera indisciplina partidária e excessos de barganhas entre o Executivo e o Legislativo $^{8}$. Esse sistema eleitoral contrasta com o sistema de lista fechada, como é o caso uruguaio, no qual o eleitor só vota em partidos, ficando limitada a escolha de preferências (Klein, 2007).

Essa estrutura institucional favorece a autonomia das campanhas dos candidatos a cargos de representação. Nessa interpretação, as características do sistema político e do sistema eleitoral influenciariam os candidatos a fazer suas campanhas com grande autonomia em relação ao partido. A bancada eleita por um partido é, sobretudo, o resultado agregado da ação de diversos candidatos individuais. Os partidos são compostos, na maior parte, por um grupo de candidatos sem quaisquer identidades ideológicas ou programáticas comuns e que se organizam apenas para a disputa eleitoral. Assim, durante a campanha eleitoral, os eleitores estão expostos a uma disputa entre candidaturas individuais ou alianças partidárias que torna improvável o desenvolvimento de laços fortes entre candidatos e partidos (Kinzo, 2005).

O sucesso eleitoral de um partido tem relação direta com a presença de candidatos competitivos. Dessa forma, é muito comum que os candidatos, uma vez eleitos, se considerem desvinculados do partido. Essas características produzem situações políticas instáveis, nas quais, por exemplo, a identificação partidária é ambivalente e confusa. As pesquisas, no Brasil, têm mostrado, de forma consistente, que, na hora de votar, os eleitores consideram a pessoa do candidato mais importante do que o partido (Baquero, 2000), processo de preferência eleitoral que afeta fortemente outras atitudes políticas, servindo como ponto de referência para entender as predisposições de apoio ou rejeição a opções políticas.

Os partidos apresentam baixa identificação entre o eleitorado, com marcadas diferenças em relação ao eleitorado uruguaio.

\footnotetext{
8 Para outros autores, a estrutura institucional vigente não constitui impedimento para que esse regime funcione de maneira relativamente coerente. Nesse sentido, destaca-se o trabalho de Figueiredo e Limongi (1999) sobre a crescente disciplina partidária na Câmara de Deputados, assim como um padrão de coalizão partidária no plenário, ideologicamente coerente com as posições de direita, esquerda e centro bem definidas. Tal comportamento seria explicado pelo controle que as lideranças partidárias exerceriam sobre a agenda dos trabalhos legislativos. Nessa perspectiva, o desenho institucional brasileiro, apesar da combinação de um sistema de governo presidencialista com um sistema eleitoral que, em teoria, incentiva a fragmentação e o personalismo, apresenta um funcionamento que permite a operacionalidade das decisões legislativas, tornando relativamente estável a dinâmica política. Desse modo, o formato do sistema partidário ao longo de sua trajetória vem demonstrando maior definição, apesar do grande número de partidos que obtiveram representação na Câmara dos Deputados.
} 
A baixa identificação partidária cresceu nos últimos anos. Segundo a última pesquisa do Datafolha (2017), 71\% dos brasileiros não têm partido de preferência. Ainda de acordo com o Instituto, o percentual é o maior desde que essa pergunta começou a ser realizada nas pesquisas, em 1989. Em dezembro de 2014, $61 \%$ disseram que não tinham partido preferido.

No caso do Rio Grande do Sul, a baixa institucionalização foi matizada pela importante presença de partidos de esquerda na década de 1980. Nesse contexto político, Trindade e Noll (1991) destacam a particularidade de Porto Alegre em relação a outras capitais brasileiras.

Na capital gaúcha, existiu maior presença de uma tradição trabalhista, pois, entre 1946 e 1964, o PTB alcançou uma importante participação em organizações sociais. Essa característica fez com que a conjuntura política de Porto Alegre fosse diferente da de outras cidades no momento imediatamente posterior à democratização em 1985.

Enquanto em todas as principais cidades do Sul e do Sudeste houve um embate entre partidos de direita e partidos de esquerda, em Porto Alegre houve uma disputa no interior da própria esquerda, com o PDT ganhando em 1986 a primeira eleição posterior à democratização e a Frente Popular ganhando a eleição seguinte (Avritzer, 2009).

\section{Influência da dinâmica político-partidária nas IPs}

Um dos primeiros atos do governo de Tabaré Vázquez foi a promulgação da Resolução no 133 BIS/90, de 28 de fevereiro de 1990, 13 dias depois de haver alcançado o governo municipal, criando 18 centros comunais zonais (CCZs) e as assembleias deliberantes, como órgãos de participação dos vizinhos.

As assembleias deliberantes foram pensadas como órgãos de participação direta, mas sua natureza era apenas consultiva. Dessa forma, o grau de poder de decisão dos cidadãos era baixo, pois quem participava das assembleias e das comissões (nas quais os cidadãos de forma individual ou representando as organizações de bairro poderiam participar) não tinha nenhuma garantia de que suas propostas seriam levadas em consideração. Apesar de as assembleias não terem poder de decisão, foi em seu âmbito que se discutiu o Plano Quinquenal da Intendência, poucos meses depois de implementada a DP. Foi nesse contexto que ocorreu a maior participação e realizaram-se as demandas, reunindo entre 20 e 25 mil moradores (Goldfrank, 2002).

O sistema político uruguaio limitou a ação de formas de democracia direta. Em 1990 todos os partidos de oposição manifestaram reações contrárias ao projeto da FA. Os partidos tradicionais uruguaios mobilizaram toda a sua estrutura política nacional e conseguiram impugnar o projeto original. Como consequência, a FA teve que encontrar brechas legais e alcançar um acordo político com a oposição. Nessas condições, foram criadas as juntas locais, esferas de participação político-partidária que adquiriram grande 
protagonismo, eclipsando os mecanismos de representação social, isto é, os conselhos de vizinhança $(\mathrm{CVs})^{9}$.

A esquerda argumentou que foi limitada em suas ambições de aprofundar a democracia por esse impedimento inicial. Entretanto, a FA foi crescendo eleitoralmente durante toda a década de 1990. Ela governa o departamento de Montevidéu há 25 anos e governa o país desde 2004. Toda essa hegemonia política, entretanto, não provocou a busca por alternativas para retomar um modelo centrado em assembleias de participação direta da população, como no projeto original.

O sistema político impôs sua lógica a instituições que tinham a finalidade de ampliar a participação para além dos partidos políticos. Os CVs visavam a uma nova forma de representação baseada na participação individual ou mediante organizações territoriais de atores sociais sem filiação partidária. Os discursos dos engenheiros institucionais da DP afirmavam a necessidade de uma mudança na forma histórica de fazer política em nível municipal, passando-se de uma lógica partidária para uma lógica de defesa dos interesses territoriais. Entretanto, nossa pesquisa, que teve como referência empírica os atores participantes dos CVs, não verificou esse tipo de participação. Constatamos a presença, de forma hegemônica, de pessoas com uma longa trajetória na política partidária da esquerda, com fortes vínculos com sindicatos e, em menor medida, com cooperativas e associações de moradores. Dessa forma, a partidocracia uruguaia, revigorada pela ação política da FA, impôs-se nos novos canais de representação desenhados para a participação da sociedade civil. Diferentemente do OP porto-alegrense, a DP não incorporou setores tradicionalmente excluídos das decisões políticas ${ }^{10}$. Por outro lado, ao enfatizar os mecanismos representativos, reproduziu um tipo de participação tradicional, por meio da eleição dos representantes por voto secreto. Esse tipo de participação muitas vezes ficou condicionado pela militância políticopartidária.

Veneciano (2008) também encontra uma correlação entre militância partidária e participação nos CVs, identificando trânsitos entre os atores da sociedade civil e da sociedade política. A partir de uma pesquisa qualitativa nas eleições realizadas nessas entidades - no período de 1993 a 2006 -, observa que, ao longo do tempo, os setores mais participativos vão evolucionando e reciclando-se dentro de suas possibilidades.

\footnotetext{
9 Em 1990, os partidos históricos uruguaios, o Partido Colorado e o Partido Nacional, conseguiram impugnar, por meio de recursos jurídicos, o projeto original - que possibilitava canais de participação mais direta através de assembleias deliberantes. A impugnação do projeto é um ponto central da tese de Goldfrank (2002) sobre a importância da institucionalização partidária no Uruguai, pois os fortes partidos de oposição, com raízes históricas na sociedade uruguaia, organizaram uma intensa campanha contra o projeto da DP por temor de perder vínculos com a sociedade. Assim, Brancos e Colorados, como membros da Junta Departamental, tinham a possibilidade legal de reunir assinaturas e apresentá-las no Parlamento Nacional, impugnando, dessa forma, os atos normativos do intendente. Eles lograram usar esse recurso para cancelar a norma que criou a descentralização.

${ }_{10}$ Apesar do predomínio dos eleitores de baixa renda, os representantes, isto é, os conselheiros eleitos, têm renda acima da renda média da população. A intenção original era a de que os setores excluídos fossem sobrerrepresentados no nível regional, ou seja, que houvesse aumento no número de pessoas com baixa renda que atuassem com representantes dos moradores (Veneciano, 2008).
} 
Militantes partidários convertem-se em militantes "socioterritoriais", e outros, que emergem da dimensão local, desenvolvem verdadeiras carreiras políticas (conselheiro, edil local, edil departamental) ou penetram em organizações sociais.

Para a autora, a participação na DP está "esquerdizada". Essa interpretação se justifica devido ao discurso de esquerda, desde a campanha eleitoral por meio da qual alcançou o governo municipal (1990), ter tido como proposta central a democracia popular mediante a descentralização. A cidadania de esquerda tem demonstrado uma atitude mais voltada à participação.

Nesse sentido, nos primeiros anos da experiência da DP, quando existia maior expectativa dos militantes de esquerda, nos CCZs em que a FA tem melhor votação, a participação dos cidadãos (medida em número de pessoas que votam nas eleições dos CVs) aumentou. Entretanto, a partir de 2004, ocorre um fenômeno contrário, isto é, nos CCZs em que a FA tem maior quantidade de votos, a participação se estanca ou decresce (Veneciano, 2008). Com base nesses dados, podemos interpretar que a participação na DP está fortemente condicionada pela ação da militância de esquerda.

No caso uruguaio, as identidades partidárias, num país marcado pela centralidade dos partidos, parecem ter exercido uma influência negativa sobre a ampliação da participação. Nos últimos anos, a participação diminuiu. Menos pessoas querem se candidatar ao cargo de conselheiro e menos pessoas votam nessas eleições. Também existe uma alta desistência, por parte dos eleitos, nos primeiros meses de atuação.

As lealdades partidárias limitam a participação de cidadãos sem vínculos partidários e sem identidades de esquerda, pois os CVs são identificados pela população e pelos agentes políticos como uma instituição de oposição ao governo, que serve para a ação política partidária, dominada pela FA.

Esse argumento se sustenta em outros estudos internacionais, nos quais são apontadas relações entre pluralização e participação. Nesse sentido, Ganuza (2007) observa que, na grande maioria dos casos, em nível internacional, aqueles processos que se podem considerar mais maduros, devido à sua estabilidade no tempo, são os mais plurais em relação à participação cidadã, isto é, aqueles nos quais participam setores com diferentes tendências partidárias e ideológicas, idades, gêneros e localizados em territórios diversos.

A influência de diferentes sistemas políticos nas formas de participação dos dois países manifesta-se, também, no nível das aspirações dos militantes individuais para carreiras políticas. No Uruguai, os vínculos de fidelidade partidária, por parte do eleitor, são fortes e foram construídos historicamente por diferentes mecanismos. Os partidos Branco e Colorado construíram vínculos baseados em significações afetivas e tradicionais. A FA visou construir os laços de fidelidade a partir de vínculos programáticos/ideológicos. O peso das identidades partidárias manifestou-se nos discursos dos entrevistados. Os conselheiros montevideanos que aspiravam ser políticos profissionais estavam condicionados pelo interesse do partido. Nessa perspectiva, afirmavam que, para serem 
candidatos, deviam desenvolver uma carreira dentro do partido. Entre os delegados de Porto Alegre, essa possibilidade aparecia como mais remota, pois predominavam os discursos antipolítica. Os delegados do OP que afirmavam a possibilidade de construir uma carreira política profissional consideravam seu projeto como uma realização individual, não partidária ou ideológica. No entanto, a maioria dos delegados e conselheiros, nas duas cidades, não manifestou uma grande motivação para construir uma carreira política profissional.

As entrevistas (E) que realizamos em Porto Alegre revelaram que as lideranças populares que surgem nos âmbitos dos bairros têm uma trajetória bastante flutuante por diversos partidos. Esse fenômeno contrasta com a realidade dos atores das instituições participativas da cidade de Montevidéu. Na capital uruguaia, o Conselho de Vizinhança está hegemonizado pela participação de militantes da FA. No Uruguai, quando perguntávamos aos conselheiros se estariam dispostos a ser candidatos a um cargo representativo, a maioria respondia argumentando que seriam candidatos se o partido assim o determinasse; portanto, destacavam a importância do interesse do partido sobre as candidaturas individuais. Além disso, afirmavam que, para ser candidato, é necessário ter uma trajetória dentro do partido. Por exemplo:

Para ser candidata é necessário o apoio do partido, eu não tenho esse apoio. É necessário pertencer a um setor e depois é necessário negociar. O setor que tem mais votos é que vai designar candidatos (incluídos cargos de confiança). Para ser candidato é necessário fazer carreira num setor. Agora são os setores que impõem (E5).

Para candidatar-me a edil tenho que pertencer a um setor (E7).

Sou muito novo (dentro do partido) e dentro do partido existem degraus (E9).

Pretensões pessoais não tenho, eu estou para o que diga o partido (E10).

No Brasil, as pessoas participam majoritariamente de campanhas eleitorais sem vínculos partidários. Nesse sentido, a maioria dos conselheiros e delegados entrevistados afirmaram que recebiam propostas de participação em diversos partidos. Eles realizaram campanhas eleitorais para candidatos sem levar em conta a que partido pertenciam. Ao comparar os dados do OP de Porto Alegre com a descentralização participativa de Montevidéu, observamos que na capital gaúcha, diferentemente de Montevidéu, a participação ocorreu com um menor índice de identificação partidária.

A maioria (delegados) não são filiados a partidos políticos, mas na hora fazem campanha para o governo. Quem Ihes oferecer mais, eles vão. Eles podem criticar o governo, mas na campanha apoiam o governo. No tempo do PT quase todas as associações faziam campanha para o PT (E1, Porto Alegre). 
É comum que delegados e conselheiros sejam convidados a filiar-se a partidos políticos, acabam aproveitando o momento da popularidade. Teve vários convites para filiar-me em partidos, mas eu achei de bem ficar de fora. (...) eu gosto [de] ver os projetos dos vereadores. A campanha política eu acho importante, necessária e gosto (E10, Porto Alegre).

Eles fazem campanha eleitoral, muitas vezes como cabos eleitorais de candidatos, mas não se identificam com partidos (E6, Porto Alegre).

A maioria dos delegados não participa (em partidos). Se fosse para ganhar alguma coisa até participavam. Antes havia mais vínculos partidários (E11, Porto Alegre).

Os delegados se vinculam aos partidos com demandas imediatas, sem o peso de uma tradição partidária. Muitos dos novos delegados que entrevistamos tinham pouco conhecimento sobre o funcionamento do OP, mas sabiam que participar era o mecanismo que gera uma possível solução para suas necessidades. Assim, a participação não está condicionada por adesão partidária, mas pela realização de demandas, demonstrando a lógica pragmática dos participantes. Nesse sentido, pesquisas apontam que a partir de 2004 o índice de demandas concluídas foi relativamente baixo, quando as demandas em andamento superam as concluídas. Na última administração do PT, existiam 963 demandas do OP em aberto, número que saltou na gestão peemedebista para 1.532. Concomitantemente à diminuição de demandas concluídas, ocorre uma forte queda na participação (Rennó e Souza, 2012).

Como destacamos anteriormente, os dados do Latinobarômetro (2013) apontam marcadas diferenças na visão sobre política partidária entre cidadãos brasileiros e uruguaios. No caso brasileiro, a visão personalista predomina sobre os partidos. Também nossas entrevistas reforçam essas pesquisas. Nesse sentido, existe uma diferença importante nos depoimentos dos entrevistados de Montevidéu comparados aos de Porto Alegre. Os delegados do OP têm fortes discursos antipartido e antipolítica, e concebem os partidos e a política como uma esfera de interesses particulares que muitas vezes não coincidem com o interesse da comunidade. A identidade "comunitária" manifesta uma forte crítica à política partidária. Nessa visão a liderança comunitária não deve defender interesses partidários.

Nunca fui filiada a partido, eu sempre fui comunidade, liderança comunitária não pode ter partido. Porque independente de quem estiver de prefeito a gente tem que garantir as obras da comunidade (E2, Porto Alegre).

Se eu pudesse terminava com a política no Brasil devido ao desmande. Existe muita impunidade, falta de leis (...) o que está acontecendo no Brasil é uma impunidade muito grande (E7, Porto Alegre). 
Pesquisas sobre o processo de seleção de candidatos no Brasil demonstram que os partidos ordenam a composição de suas listas a deputados ou vereadores atribuindo valores diferenciados aos candidatos. Nessa lógica partidária, são incluídos, em primeiro lugar, candidatos com um potencial eleitoral elevado e com grandes chances de serem eleitos. Em segundo lugar, candidatos com votação expressiva, mas inferior ao do caso anterior. Por último, os candidatos sem chances de serem eleitos e com poucos votos, mas mesmo assim com possibilidades de contribuir com o partido (Carneiro, 2009).

Muitos desses candidatos a vereador ou a deputado vão recrutar cabos eleitorais ou candidatos entre líderes do movimento comunitário, embora tenham poucas chances de se eleger. Esse fenômeno explicaria por que tantos de nossos entrevistados em Porto Alegre recebem muitas propostas de filiação partidária. A baixa identidade partidária dos eleitores e dos políticos permitiu, por exemplo, que lideranças comunitárias sem fidelidades partidárias, no final da década de 1980, participassem do projeto impulsionado pelo PT.

Em nossas entrevistas, a maioria dos delegados tinha sido convidada a participar de diversos partidos, pois os líderes comunitários podem trocar de partido sem perder capital político. Perante uma troca de partidos eles podem manter sua identidade comunitária, que, junto com as caraterísticas pessoais, está acima dos fracos partidos.

Não tenho preferência por partidos, voto nas pessoas, apoio o que elas fazem independente de partidos (E13, Porto Alegre).

A política não me atrai (...). Eu voto na pessoa, no ser humano. Fui convidada por vários partidos a participar como filiada (E7, Porto Alegre).

\section{Dinâmicas partidárias e mudanças na participação na década de 2000}

Entre os participantes nas assembleias do OP, O PT, nos anos 1990, aparece como o partido amplamente majoritário nas preferências, chegando a quase $40 \%$. Entretanto, na pesquisa de 2005, houve um decréscimo moderado nas preferências por esse partido, juntamente com um aumento dos porcentuais dos partidos que formaram a nova coalizão de governo, a partir de 2005.

No ano de 2004, o PT perde a prefeitura para José Fogaça, então membro do Partido Popular Socialista (PPS). Fogaça ganha a eleição defendendo a "participação popular" e a continuação do programa de OP. Nas eleições de 2008, reelege-se prefeito, agora pelo PMDB. Diferentemente da eleição anterior, o prefeito reeleito faz campanha após ter mantido o OP em funcionamento, apesar de diminuir a centralidade que o programa tinha nas administrações petistas (Rennó e Souza, 2012).

No novo contexto político, a soma dos partidos vinculados ao governo, Partido Popular Socialista (PPS), Partido Trabalhista Brasileiro (PTB), Partido do Movimento Democrático Brasileiro (PMDB), Partido Democrático Trabalhista (PDT), Partido 
Progressista (PP) e Partido da Social Democracia Brasileira (PSDB), aumentou de 3,9\%, em 2002, para 14\% das preferências dos participantes das assembleias do OP em 2005, o que representa um crescimento de mais de 200\% (Fedozzi, 2007). Esses dados demonstram que, num cenário de baixa identidade partidária e alta volatilidade eleitoral, os moradores da periferia podem aderir com grande facilidade aos partidos governistas.

Muitos delegados e conselheiros, de forma semelhante aos participantes das assembleias, terminam aderindo a partidos vinculados ao governo em função de uma lógica pragmática de conseguir recursos para a comunidade. Um indicador dessa possível cooptação pode expressar-se empiricamente na adesão dos representantes populares aos partidos da base do governo de turno.

As análises do conselho do orçamento participativo (Tabela 1) demonstram que nos últimos anos ocorreu um processo de alteração de filiações partidárias dos conselheiros, com maior adesão dos conselheiros aos partidos da base do governo atual.

Tabela 1

Filiação partidária entre os conselheiros titulares, 2005, 2009, 2012

\begin{tabular}{|l|c|c|c|c|c|c|}
\hline \multirow{2}{*}{ Filiação partidária } & \multicolumn{2}{|c|}{2005} & \multicolumn{2}{c|}{2009} & \multicolumn{2}{c|}{2012} \\
\cline { 2 - 7 } & Casos & $\%$ & Casos & $\%$ & Casos & $\%$ \\
\hline Sem filiação & 23 & 53,5 & 20 & 45,0 & 17 & 37,0 \\
\hline PDT & 2 & 4,7 & 2 & 4,5 & 7 & 15,2 \\
\hline PT & 6 & 14,0 & 7 & 15,9 & 3 & 4,3 \\
\hline PTB & 3 & 7,0 & 4 & 9,1 & 2 & 8,7 \\
\hline PMDB & 1 & 2,3 & 1 & 2,3 & 4 & 8,7 \\
\hline PPS & 2 & 4,7 & 5 & 11,4 & 4 & 8,7 \\
\hline PSB & 2 & 4,7 & 1 & 2,3 & 4 & 8,7 \\
\hline PSDB & 1 & 2,3 & - & - & - & - \\
\hline PCdoB & 3 & 7,0 & - & - & 1 & 2,2 \\
\hline PSOL & - & - & 1 & 2,3 & 2 & 4,3 \\
\hline PP & - & - & 2 & 4,5 & - & - \\
\hline PPL & - & - & - & - & 2 & 4,3 \\
\hline Total & 43 & 100,0 & 43 & 100,0 & 43 & 100,0 \\
\hline
\end{tabular}

Fonte: Fedozzi e Martins (2015).

Fedozzi e Martins (2015) apresentam algumas hipóteses explicativas para que os conselheiros adotassem essa alteração. A provável elitização política em curso seria reflexo da crise e da reconfiguração do modelo do OP de Porto Alegre. Nesse sentido, são identificados diferentes fatores interligados que compõem o contexto no qual ocorreram as mudanças das regras da participação. Um aspecto destacado refere-se à intensificação da captura de lideranças pelo governo.

Os dados indicam que existem duas tendências presentes na formação do conselho do OP. Por um lado, ocorreu uma diminuição das porcentagens de conselheiros 
sem filiação partidária, o que pode indicar um aumento da influência da variável partidária na escolha de conselheiros. Por outro lado, ocorreram mudanças na identidade partidária dos conselheiros, aumentando o número dos conselheiros favoráveis à nova administração que assumiu em 2005 (PPS, PMDB, PTB e PDT)

No caso de Montevidéu, não tivemos uma mudança de governo. A FA continua no governo municipal desde 1990; entretanto, é possível afirmar que na última década mudou a expectativa em torno da participação.

As mudanças no modelo institucional introduzidas em 2006 refletiram novas expectativas da esquerda uruguaia em relação ao tipo de participação esperada. Quando a FA assumiu o governo de Montevidéu, esperava-se uma participação massiva do campo popular. Essa expectativa refletia o contexto do final da década de 1980, marcado pela luta de uma sociedade mobilizada contra a ditadura militar e pelas concepções de esquerda que enfatizavam uma democracia baseada na ação direta dos trabalhadores.

A nova forma de participação esperada, particularmente a partir das mudanças introduzidas em 1993 com os CVs e em 2006 com o Orçamento Participativo, enfatiza a pluralidade, a universalidade e a necessidade de uma nova cultura democrática. Os promotores da DP defendem a necessidade de consolidar uma participação plural, propondo mudanças nas formas tradicionais de participação político-partidária, isto é, propondo uma nova cultura democrática.

Quando contrapomos a DP ideal aos dados empíricos pesquisados, a primeira conclusão em relação às entrevistas realizadas em duas regiões de Montevidéu é a de que a maioria absoluta dos conselheiros são militantes de esquerda vinculados ao âmbito sindical e às cooperativas e têm mais de 50 anos.

Os cidadãos que se relacionam aos problemas territoriais são pessoas de idade avançada, em geral donas de casa. Normalmente, suas trajetórias estão vinculadas a um período dramático da história uruguaia: a ditadura cívico-militar (1973-1985). Assim, grande parte do grupo de conselheiros provém de uma formação cultural vinculada ao período autoritário. Os antigos militantes de esquerda que viveram a repressão dos anos 1970 e princípio dos 1980 são parte de uma geração que sofreu a perseguição e, em muitos casos, a prisão.

A formação cultural dos conselheiros ocorreu nesse período, quando tiveram como escola política o sindicalismo e as atividades partidárias de esquerda, num contexto de forte repressão. Muitas das ações políticas desse período estavam inseridas numa lógica de ocultamento, característica que perdura no período democrático. Alguns entrevistados afirmam que há uma lógica partidária no funcionamento dos CVs, mas que essa lógica se oculta, pois "Existem pessoas que têm um modo antigo de fazer política (...) há reuniões por setores políticos dentro do conselho, mas eles dizem que não são políticos partidários" (E1, Montevidéu).

Nos depoimentos, geralmente é significada de forma negativa a defesa da esfera político-partidária. Nesse sentido, um aspecto que se reitera em várias falas dos 
entrevistados é a afirmação de que há uma confusão entre "a militância políticopartidária e a função social". Muitos dos conselheiros fazem uma distinção entre o "social" e o "político", mas afirmam que os outros não fazem tal distinção, portanto, os outros são conscientes de que se deve atuar de forma diferenciada como ator político e ator social. Entre os entrevistados mais organicamente relacionados à $F A$, essa distinção aparece como uma constante acompanhada de grande carga normativa.

A distinção social/político também está presente na planificação inicial do modelo institucional. Os dirigentes da FA aspiravam a promover a participação do maior número de pessoas, pois era comum a percepção, entre eles, de que o militante de esquerda tradicional uruguaio não sabia como abordar os problemas do bairro. Alguns trechos das entrevistas realizadas por Harnecker (1995, p. 85) com dirigentes da FA que participaram dos debates e da construção institucional da DP exemplificam o recorrente esforço de diferenciação entre militância política e social:

Não tínhamos experiência na militância social e do bairro. Tínhamos uma experiência distinta. (...) é muito diferente o relacionamento como militante político com a vizinhança do bairro e o relacionamento como vizinho de bairro com outro vizinho (...) como militantes políticos não conseguimos gerar uma discussão nos lugares correspondentes.

Essa autocrítica vai fazer parte de todo o processo da DP.

Apesar de a grande maioria dos conselheiros ser vinculada organicamente a partidos de esquerda (hegemonicamente à coalizão $F A$, e, entre estes, alguns são militantes do Partido Comunista Uruguaio), nos últimos anos, foram eleitos conselheiros ligados aos partidos tradicionais que, de forma muito explícita, justificam sua participação como uma orientação partidária. Eles assumem a participação nos CVs como uma ação explicitamente guiada por uma lógica de adesão partidária, que os militantes da FA não querem assumir. Para um funcionário municipal que participou da elaboração da engenharia institucional da DP, a atitude dos partidos tradicionais é mais "honesta":

A participação político-partidária foi uma característica e incluso tende a aprofundar-se. Por exemplo, o Partido Nacional (PN) explicitamente busca a participação de militantes próprios. A FA o faz sem dizê-lo. O PN é mais honesto, porque, se, por um lado, se afirma que os CV visam a participação social e se participa de forma partidária, [esse fato] é perverter a proposta, isso é gravíssimo. Pois isso leva que os conselheiros sigam uma lógica partidária e não vicinal (E22, Montevidéu).

Se, para os militantes de esquerda, a distinção entre o social e o político aparece como um deve ser, para os atores dos partidos tradicionais, as instituições participativas são canais de expressão político-partidária, portanto, não estão condicionadas por uma normatividade que separa a esfera social da esfera política. A interpretação dos CVs 
como um lugar explícito de ação partidária é destacada pelo depoimento de um dos poucos militantes dos partidos tradicionais.

Esta esfera da representação sempre foi dominada pela esquerda. A
esquerda utiliza o CV como uma maneira de conhecer a realidade local e
obter votos. A direita percebeu que era um espaço que se estava cedendo.
Assim, a partir de 2011 , existiu uma maior participação dos partidos
tradicionais nos CVs (E9, Montevidéu).

São movimentos por vezes sutis de transformação, que nossa análise buscou captar a partir das duas experiências de participação. Nas conclusões, retomamos as linhas gerais de nossa investigação e trazemos as principais respostas que construímos acerca desse processo.

\section{Conclusões}

A tese de Goldfrank (2006) problematizou os efeitos da institucionalização partidária na implementação e definição do modelo participativo. Nosso artigo completou as observações de Goldfrank, destacando elementos que não estavam presentes na sua análise.

Nesse sentido, nos centramos na influência do sistema partidário e do sistema eleitoral nos vínculos de atores sociais e políticos na forma de participação, num período mais longo do que o analisado por Goldfrank e em dinâmicas mais individuais. Analisamos as relações fluidas dos indivíduos que atuam em organizações partidárias e em organizações da sociedade civil. Tendo como foco essas inter-relações, podemos observar que um sistema partidário pouco institucionalizado e um sistema eleitoral altamente centrado no candidato (listas abertas) favorecem um tipo de participação que se desvincula das identidades partidárias.

Observamos que a influência partidária pode gerar efeitos diversos. Sistemas partidários pouco institucionalizados, com sistema eleitoral personalizado em nível nacional, podem coexistir com padrões de identificação partidária mais fortes em nível subnacional, como foi o caso de Porto Alegre na gênese do OP. Nesse contexto, no final da década 1980, a construção do PT esteve associada à formação de um movimento sindical e comunitário. Este último influenciou a formação da ideia de compartilhamento das decisões sobre o orçamento público, que vai se consolidar institucionalmente na década de 1990.

Nessas décadas, os partidos de esquerda foram fortalecidos adquirindo caraterísticas de partidos institucionalizados, de forma mais acentuada na capital gaúcha, contrastando com o cenário nacional de uma baixa institucionalização partidária. "Militantes múltiplos", vinculados a partidos e a associações da sociedade civil, não tiveram partidos de oposição fortes para limitar um projeto participativo inovador. $\mathrm{O}$ 
modelo institucional de participação baseado em assembleias e instâncias de representação foi compatível com a baixa institucionalização partidária da oposição, pois os moradores da periferia puderam demandar serviços com base na identidade de comunidade, mantendo uma imagem negativa sobre os partidos.

No entanto, nos anos 2000, com as mudanças no governo municipal, muitos dos membros das instâncias representativas do OP vão aderir de forma pragmática aos novos governos, demonstrando que as identidades partidárias não formaram raízes profundas entre muitos dos setores populares porto-alegrenses. Também observamos que o baixo enraizamento dos partidos na sociedade pode gerar efeitos negativos para uma melhor qualidade da participação, isto é, pode aumentar as probabilidades de cooptação dos governos sobre associações e representantes de organizações populares.

No caso da cidade de Montevidéu, os CVs estão perdendo participantes. Esse fenômeno se expressa na contínua redução de pessoas que aspiram a ser candidatos e manter-se no cargo de conselheiro. Na capital uruguaia, a participação está diretamente relacionada à militância partidária. A "partidocracia", expressa em lealdades partidárias, parece orientar decisivamente as práticas políticas e sociais. Esse fato limita a participação de cidadãos sem vínculos partidários e sem identidades de esquerda, pois o CV é identificado como uma instituição da Frente Ampla.

Concluímos destacando o paradoxo das relações estudadas. Por um lado, há o caso uruguaio, para o qual a maioria das pesquisas internacionais destaca a alta adesão às instituições e aos valores democráticos - que seriam propícios ao surgimento e à sobrevivência de instituições democráticas (Inglehart e Welzel, 2009). Constatamos que, nesse país, a alta institucionalização partidária limita a ampliação da participação de novas experiências democráticas.

Por outro lado, sugerimos que no caso brasileiro - em que as pesquisas fundamentadas na noção de cultura política apontam para o baixo enraizamento dos valores democráticos e de identidades partidárias - foi possível um tipo de participação mais plural por meio do OP de Porto Alegre. Contudo, também gerou maior propensão à captura do público participante por parte dos governos.

\section{Referências bibliográficas}

AVRITZER, L. A moralidade da democracia. Ensaios em teoria habermasiana e teoria democrática. Belo Horizonte: Editora UFMG, 1996.

. "Um desenho institucional para o novo associativismo". Lua Nova, no 39, 1997.

AVRITZER, L. Orçamento participativo e a teoria democrática: um balanço crítico. In: AVRITZer, L.; NAVARRo, Z. (orgs.). A inovação democrática no Brasil. O orçamento participativo. São Paulo: Cortez, 2003.

"Instituições participativas e desenho institucional: algumas considerações sobre a variação da participação no Brasil democrático". Opinião Pública, Campinas, vol. 14, n 1, 2008. 
2009.

. Participatory institutions in democratic Brazil. Baltimore: John Hopkins University Press,

"Sociedade civil e Estado no Brasil: da autonomia à interdependência política". Opinião

Pública, Campinas, vol. 18, n², nov., 2012.

BAIERLE, S. "Um novo princípio ético-político: prática social e sujeito nos movimentos populares urbanos em Porto Alegre nos anos 80". Dissertação de Mestrado em Ciência Política. Universidade Estadual de Campinas. Campinas, 1992.

BAQUero, M. A vulnerabilidade dos partidos políticos e a crise da democracia na América Latina. Porto Alegre: Editora da UFRGS, 2000.

. Democracia e desigualdades na América Latina: novas perspectivas. Porto Alegre: Editora da UFRGS, 2007.

Barreto, A. "Eleições municipais comparadas: a escolha do chefe do Executivo no Brasil e no Uruguai e o impacto sobre os sistemas partidários locais (2000-2005)". Revista Brasileira de Ciência Política, Brasília, vol. 7, p. 285-318, jan.-abr., 2012.

BRUERA, S. "Apuntes para una evaluación del proceso de descentralización desde las Comisiones Vecinales". In: Participación Ciudadana y Relaciones e Gobierno. Ciedur, Ciesu, ICP, Fesur. Montevideo, 1993.

CAetAno, G.; Rilla, J. El sistema de partidos: raíces y permanencias. In: Caetano, G., et al. De la tradición a la crisis. Pasado y presente de nuestro sistema de partidos. Montevideo: CLAEH/EBO, 1991.

Calvo, J. J. (coord.). Atlas sociodemográfico y de la desigualdad del Uruguay. Montevideo: Ediciones Trilce, 2013.

CARDARELlo, A. "La reelección inmediata del ejecutivo a nivel subnacional: un estudio de tres casos". Tese de Doutorado em Ciência Política. Universidade Federal do Rio Grande do Sul, Porto Alegre 2009.

CARneiro, A. "Processo de seleção de candidatos ao cargo de deputado federal no estado do Rio de Janeiro - organizando as peças do quebra-cabeça". Tese de Doutorado em Ciência Política. Instituto Universitário de Pesquisas do Rio de Janeiro. Rio de Janeiro, 2009.

CHAVES, D. La nueva izquierda en América Latina - sus orígenes y trayectoria futura. Bogotá: Norma, 2005.

Cohen, J.; ARATo, A. Sociedad civil y teoria política. México: Fondo de Cultura Económica, 2001.

Datafolma, Pesquisa de Preferência Partidária, entre 21 e 23/06/2017. 2017. Disponível em: <http://media.folha.uol.com.br/datafolha/2017/06/26/7b9816148d0e227a8453fcfc21b7d410a3a36f 87.pdf>. Acesso em: 22 fev. 2019.

Doglio, N.; Senatore, L.; YaffÉ, J. Izquierda política y sindicatos en Uruguay (1971-2004). In: LANZARO, J. (coord.). La izquierda uruguaya entre la oposición y el gobierno. Montevideo: Fin de Siglo, 2004.

DUVERGER, M. Os partidos políticos. Brasília: Editora Universidade de Brasília, 1980.

FEDozzI, L. O poder da aldeia. Gênese e história do orçamento participativo de Porto Alegre. Porto Alegre: Tomo Editorial, 2000.

. Observando o Orçamento Participativo de Porto Alegre. Análise histórica de dados: perfil social e associativo, avaliação e expectativas. Porto Alegre: Tomo Editorial, 2007. 
Fedozzi, L.; MARTINS, A. "Novas instituições participativas, processos de elitização e o orçamento participativo de Porto Alegre". Anais do $35^{\circ}$ Encontro Anual da Anpocs, Caxambu (MG), 2013.

Fedozzi, L.; MARTINS, A. "Trajetória do orçamento participativo de Porto Alegre: representação e elitização política". Lua Nova, São Paulo, no 95, p. 181-223, 2015.

FERLA, P., et al. Descentralización y participación democrática en Montevideo. Los consejos vecinales um aporte sobre la cuestión metropolitana. Defensoría del Vecino: Montevideo, 2012.

Figueiredo, A.; Limongi, F. Executivo e Legislativo na nova ordem constitucional. Rio de Janeiro: Editora FGV, 1999.

FIlgueIRA, C. Movimientos sociales en la restauración del orden democrático: Uruguay, in movimientos sociales en el Uruguay de hoy. Montevidéu: EBO, 1985.

FUNG, A. Receitas para esferas públicas: oito desenhos institucionais e suas consequências. In: Coelho, V.; NoBRe, M. (orgs.). Participação e deliberação. Teoria democrática e experiências institucionais no Brasil contemporâneo. São Paulo: Editora 34, 2004.

GANuZA, E. Tipología y modelos de los presupuestos participativos en España, documentos de trabajo 1307. Córdoba: Instituto de Estudios Sociales Avanzados, 2007.

Genro, T.; SouzA, U. O orçamento participativo: a experiência de Porto Alegre. São Paulo: Fundação Perseu Abramo, 1997.

GIMENES, E. "Mobilização cognitiva e apartidarismo: a relação dos eleitores com os partidos políticos na América Latina (2006-2014)". Anais do $39^{\circ}$ Encontro Anual da Anpocs, Caxambu (MG), 2015.

GoLDFRANK, B. "The fragile flower of local democracy: a case study of decentralization/participation in Montevideo". Politics \& Society, vol. 30, n 1, 2002.

. "Los procesos de presupuesto participativo en América Latina: éxito, fracaso y cambio". Revista de Ciencia Política, Santiago, vol. 26, n² 2, 2006.

GRILL, I. "A herança trabalhista no Rio Grande do Sul: parentesco, carisma e partidos". Sociedade e Cultura, Goiânia, vol. 7, n², p. 225-236, 2004.

Gugliano, A. "Participação e governo local comparando a descentralização de Montevidéu e o orçamento participativo de Porto Alegre". Sociologia, Problemas e Práticas, Lisboa, n 46, 2004.

HABERmAS, J. Direito e democracia. Entre facticidade e validade. Rio de Janeiro: Tempo Brasileiro, 2003.

HARNECKER, M. Un pueblo que se constituye en gobierno. Montevideo: Lom Ediciones, 1995.

Houtzager, P. P.; Gurza lavalle, A.; Acharya, A. Atores da sociedade civil e atores políticos: participação nas novas políticas democráticas. In: AVRITZER, L. (org.). A participação em São Paulo. São Paulo: Editora Unesp, 2004.

INGLehaRT, R.; Welzel, C. Modernização, mudança cultural e democracia: a sequência do desenvolvimento humano. São Paulo/Brasília: Francis \& Verbena, 2009.

KInzo, M. Os partidos no eleitorado: percepções públicas e laços partidários no Brasil. Anais do XXVII Encontro Anual da Anpocs, Caxambu (MG), 2005.

KLEIN, C. O desafio da reforma política: consequências dos sistemas eleitorais de listas abertas e fechadas. Rio de Janeiro: Mauad, 2007.

LATINOBARÓMETRO. Santiago, 2013. Disponível em: <http://www.latinobarometro.org/documentos/LATBD_INFORME_LB_2013.pdf>. Acesso em: 17 out. 2017. 
Lissidini, A. Uruguay y la centralidad de la política. In: CAVAROzZI, M.; MedinA, J. El asedio a la política. Los partidos latinoamericanos en la era liberal. Rosario: Editorial Homosapiens, 2002.

LÜCHMANN, L. "Possibilidades e limites da democracia deliberativa: a experiência do orçamento participativo de Porto Alegre". Tese de Doutorado em Ciências Sociais. Universidade Estadual de Campinas. Campinas, 2002.

MaInWARING, S. Sistemas partidários em novas democracias: o caso do Brasil. Porto Alegre/Rio de Janeiro: Mercado Aberto/Editora FGV, 2001.

MaInWARING, S.; SCULly, T. La construcción de instituciones democráticas. Sistemas de partidos en América Latina. Santiago: Cieplan, 1995.

MAINWARING, S.; TORCAL, M. "Teoria e institucionalização dos sistemas partidários após a terceira onda de democratização". Opinião Pública, Campinas, vol. 11, n² 2, 2005.

Meneguello, R. PT: a formação de um partido (1979-1982). Rio de Janeiro: Paz e Terra, 1989.

MirzA, C. Movimientos sociales y sistemas políticos en América Latina: la construcción de nuevas democracias. Buenos Aires: Clacso, 2006.

MISCHE, A. "De estudantes a cidadãos: redes de jovens e participação política". Revista Brasileira de Educação, vol. 6, 1997.

PAOLI, M. Movimentos sociais no Brasil: em busca de um estatuto político. In: HellmanN, M. (org.). Movimentos sociais e democracia no Brasil. São Paulo: Marco Zero, 1995.

REAL DE AzúA, C. Partidos, política y poder en el Uruguay (1971 - coyuntura y pronóstico). Montevideu: Facultad de Humanidades y Ciencia, 1988.

RENNÓ, L.; SouzA, A. "A metamorfose do orçamento participativo: mudança de governo e seus efeitos em Porto Alegre". Revista de Sociologia e Política, Curitiba, vol. 20, n 41, 2012.

RiBEIRo, E.; BorBA, J. "Os determinantes da participação no orçamento participativo: um estudo comparado entre Porto Alegre e Montevidéu". Anais do $34^{\circ}$ encontro anual da Anpocs, Caxambu (MG), 2010.

SAmUELS, D. "Incentives to cultivate a party vote in a candidate-centric electoral system". Comparative Political Studies, vol. 32, n 4, 1999.

2008. . "A evolução do petismo (2002-2008)". Opinião Pública, Campinas, vol. 14, no 2, nov.,

SARTORI, G. Comparación y método comparativo. In: SARTORI, G.; MORLINO, L. (comps.). La comparación en las ciencias sociales. Madrid: Editoria Alianza, 1994.

Serna, M. Reconvenção democrática das esquerdas no Cone Sul: trajetórias e desafios em Argentina, Brasil e Uruguai. São Paulo: Editora Edusc, 2003.

Silva, M. "Construção da participação popular: análise comparativa de processos de participação social na discussão pública do orçamento em municípios da região metropolitana de Porto Alegre/RS". Tese de Doutorado. Universidade Federal do Rio Grande do Sul. Porto Alegre, 2001.

SousA, M. A cultura política do "batllismo" no Uruguai (1903-1958). São Paulo: Fapesp, 2003.

Teixeira, A. C. C.; Albuquerque, M. C. Orçamentos participativos: projetos políticos, partilha do poder e alcance democrático. In: Dagnino, E.; OlverA, A. J.; PANFichi, A. (orgs.). A disputa pela construção democrática na América Latina. São Paulo: Paz e Terra; Campinas: Editora Unicamp, 2006. 
TRINDADE, H.; Noll, M. Rio Grande da América do Sul: partido e eleições (1823-1990). Porto Alegre: UFRGS, 1991.

VeneCIANO, A. "La descentralización del gobierno municipal de Montevideo en el marco de la reforma del Estado (1990-2001)". Tese de Doutorado. Instituto Universitário de Pesquisas do Rio de Janeiro. Rio de Janeiro, 2004.

"Participación ciudadana en la descentralización de Montevideo: aprendizajes y reflexiones desde los noventa". Revista Uruguaya Ciencia Política, Montevideo, vol. 17, n 1, 2008.

YAfFÉ, J. Competencia interna y adaptación partidaria en el frente amplio de Uruguay. México: Perfiles Latinoamericanos, 2013.

\begin{abstract}
Civil society, political parties and interrelationships: a comparative study between Porto Alegre and Montevideo

This article aims to carry out a comparative study between the Participative Budget (PB) from Porto Alegre and the Participative Decentralization from Montevideo, having as the analytical centre the role played by the party-political systems in the two countries. In this sense, the investigation intends to offer some elements which help to answer the following question: to what extent the distinctive nature from the party systems from Brazil and Uruguay and their relations with the civil society and the State can change the elaboration and functioning of new Participative Institutions? In the analysis we aimed to break up the normative dichotomy which separates the civil society from the political one present in most of the academic works about participative institutions in Brazil. After an investigation based on secondary sources about the two experiences and primary sources with members of the Neighboring Councils, in Montevideo, and with delegates of PB, in Porto Alegre, the conclusion was on the distinctive influences of the political systems in the studied cases. In Montevideo, predominates, hegemonically, the participation of people with a long trajectory in the political party. In the case of PB from Porto Alegre, the low institutionalization of the party-political system allowed that participants were not constrained by the party identities.
\end{abstract}

Keywords: participative democracy; civil society; political parties

\title{
Resumen
}

Sociedad civil, partidos políticos e interrelaciones: un estudio comparativo entre Porto Alegre y Montevideo

Este artículo tiene por objetivo realizar un estudio comparativo entre el Presupuesto Participativo de Porto Alegre y la Descentralización Participativa de Montevideo, teniendo como centro analítico el papel desempeñado por el sistema político-partidario en los dos países. En este sentido, la investigación pretende ofrecer elementos que auxilien a responder la siguiente pregunta: ¿hasta qué punto la naturaleza distinta de los sistemas partidarios de Brasil y de Uruguay y sus ligaciones con la sociedad civil afectan la creación y el funcionamiento de las Instituciones Participativas? En el análisis se buscó romper con la dicotomía normativa que separa la sociedad civil de la sociedad política, presente en gran parte de los trabajos académicos sobre Instituciones Participativas en Brasil. Posterior a la investigación, basada en fuentes secundarias sobre las dos experiencias y fuentes primarias (entrevistas realizadas con integrantes de los Consejos Vecinales en Montevideo y delegados del Presupuesto Participativo de Porto Alegre), se concluyó que en Montevideo predomina hegemónicamente la participación de personas de larga trayectoria en política partidaria. En el caso de Porto Alegre, la baja institucionalización partidaria permitió que los participantes no fuesen limitados por identidades partidarias.

Palabras clave: democracia participativa; sociedad civil; partidos políticos 


\section{Resumé}

Société civile, partis politiques et interrelations: une étude comparative entre Porto Alegre et de Montevideo

Cet article a pour but de réaliser une étude comparative entre le Budget Participatif (BP) de Porto Alegre et la Décentralisation participative de Montevideo, elle aura comme centre d'analyse le rôle joué par les systèmes des partis politiques dans les deux pays. Dans ce sens, l'investigation a l'intention d'offrir des éléments qui vont aider à répondre à la question suivante: à quel point la nature distincte des systèmes des partis du Brésil et de I'Uruguay et leurs liens avec la société civile affectent-ils la création et le fonctionnement des nouvelles Institutions participatives? Dans I'analyse, on a cherché à rompre la dichotomie normative qui écarte la société civile de la société politique, présente dans la plupart des travaux universitaires sur des institutions participatives au Brésil. Après une investigation sur la base de sources secondaires sur les deux expériences et de sources primaires avec des membres du Conseil de voisins à Montevideo et avec des Délégués do BP à Porto Alegre, on a conclu qu'il existe différentes influences des systèmes politiques dans les cas analysés. À Montevideo il y a une prédominance, hégémonique, de la participation des personnes qui ont une longue trajectoire dans la politique partisane. Dans le cas du BP de Porto Alegre, la faible institutionnalisation du système des partis politiques a permis aux participants de n'être pas contraints par les identités des partis.

Mots clés: démocratie participative; société civile; partis politiques

Artigo submetido à publicação em 13 de abril de 2018. Versão final aprovada em 6 de fevereiro de 2019.

Opinião Pública adota a licença Creative Commons CC-BY. 